\title{
TEORI MOTIVASI MCCLELLAND DAN IMPLIKASINYA DALAM PEMBELAJARAN PAI
}

\author{
Muhammad Ridho \\ Universitas Islam Negeri Sunan Kalijaga Yogyakarta \\ relrasyid@gmail.com
}

\begin{abstract}
The issue of learning achievement for students needs to be an important discussion because it can affect the education of a nation. Among the causes of low student achievement is motivation. All parties involved in education should contribute to solving the problem. This article aims to explore McClelland's motivational theory and actualize it in Islamic education (PAI) learning. The approach used is a qualitative approach by conducting literature studies or library research in accordance with the theme of the main topic. The analysis used is discourse analysis to examine the value or message contained in a text, especially about McClelland's achievement motivation theory and PAI learning. The results of this study indicate that PAI learning should contain McClelland's motivation regarding achievement motivation, power motivation, and affiliation motivation to support the interests of students. This is also supported by the argument from the Qur'an and the Hadith.
\end{abstract}

Keywords: Motivation, McClelland, Learning, Islamic Education

\begin{abstract}
Abstrak: Permasalahan prestasi belajar bagi peserta didik perlu menjadi pembahasan penting karena dapat mempengaruhi pendidikan suatu bangsa. Diantara penyebab rendahnya prestasi belajar peserta didik adalah motivasi. Semua pihak terkait dalam pendidikan hendaknya turut andil untuk menyelesaikan masalah tersebut. artikel ini bertujuan untuk mengeskplorasi teori motivasi McClelland dan mengaktualisasikannya dalam pembelajaran pendidikan agama Islam (PAI). Pendekatan yang digunakan ialah pendekatan kualitatif dengan melakukan studi literatur atau penelitian pustaka yang sesuai dengan tema bahasan pokok. Analisis yang digunakan adalah analisis wacana untuk mengkaji nilai atau pesan yang terkandung pada sebuah teks khususnya tentang teori motivasi berprestasi McClelland dan pembelajaran PAI. Hasil penelitian ini menunjukkan bahwa pembelajaran PAI hendaknya memuat motivasi McClelland mengenai motivasi prestasi, motivasi kekuasaan, dan motivasi berafiliasi untuk menunjang minat peserta didik. Hal tersebut juga didukung dalil dari Al-Qur'an dan Hadits.
\end{abstract}

Kata Kunci: Motivasi, McClelland, Pembelajaran, Pendidikan Agama Islam 


\section{PENDAHULUAN}

Kualitas pendidikan suatu negara menjadi pembahasan yang tiada akhir. Hal ini disebabkan karena kelemahan dan kekurangan dari berbagai aspek pendidikan. Beberapa diantaranya adalah kualitas pendidik, sistem pendidikan yang ruwet, dan terkendalanya sarana dan prasarana serta aspek yang lainnya. Dalam sebuah survey yang dilakukan Programme for International Student Assessment (PISA) di Paris, memaparkan bahwa Indonesia berada pada peringkat 72 dari 79 negara. Perlu diketahui bahwa survey PISA ini merupakan lembaga survey yang bertujuan untuk menilai kualitas pendidikan di dunia meliputi kemampuan membaca, matematika dan sains. ${ }^{1}$

Penyebab lainnya adalah prestasi belajar siswa yang rendah menyebabkan kurang berkembangnya pendidikan Indonesia. Sebagaimana dalam penelitian Dwi Tri Santosa mengatakan bahwa motivasi berprestasi siswa hanya 13,83 persen. ${ }^{2} \mathrm{Hal}$ tersebut terjadi karena kurangnya kesadaran untuk mengembangkan potensi siswa baik dari guru maupun dari siswa sendiri sehingga perlu adanya perbaikan maksimal terhadap proses pembelajaran khususnya aspek motivasi berprestasi.

Problematika lemahnya kualitas kinerja guru juga menjadi pertimbangan yang sangat penting, sebab guru memiliki tanggung jawab yang besar membimbing generasi penerus bangsa Indonesia. Penelitian Leonard menjelaskan bahwa 75 persen guru tidak mempersiapkan pembelajaran dengan baik. ${ }^{3}$ Kurangnya motivasi mengajar juga akan berdampak buruk bagi guru dan siswa, sehingga pembahasan tersebut perlu dikaji secara detail agar memberikan solusi yang tepat di masa mendatang.

Dari berbagai masalah di atas, dapat ditarik benang merah bahwa kurangnya motivasi dalam berprestasi tentu akan sangat mempengaruhi kualitas pendidikan suatu bangsa. Oleh sebab itu, artikel ini bertujuan untuk mengkaji teori motivasi

1 Detik.com. (2019). Peringkat 6 Terbawah, Indonesia Diminta Tinggalkan Sistem Pendidikan Feodalistik. Diakses pada 11.24 WIB, 26 Februari 2020. Dari https://news.detik.com/dw/d4811907/peringkat-6-terbawah-indonesia-diminta-tinggalkan-sistem-pendidikan-feodalistik.

${ }^{2}$ Dwi Tri Santosa, "Faktor-Faktor Penyebab Rendahnya Motivasi Belajar Dan Solusi Penanganan Pada Siswa Kelas XI Jurusan Teknik Sepeda Motor," E-Jurnal Pendidikan Teknik Otomotif-S1 13, no. 2 (2016): Hal. 14.

3 Leonard Leonard, "Kompetensi Tenaga Pendidik Di Indonesia: Analisis Dampak Rendahnya Kualitas SDM Guru Dan Solusi Perbaikannya,” Formatif: Jurnal Ilmiah Pendidikan MIPA 5, no. 3 (2016): Hal. 193. 
berprestasi McClelland. Dimana teori tersebut akan dihubungkan dengan pembelajaran PAI, sehingga dapat berkontribusi minimal dalam menganalisis secara umum masalah-masalah pendidikan di Indonesia.

\section{METODE PENELITIAN}

Penelitian ini adalah penelitian deskriptif kualitatif, yaitu penelitian yang bertujuan untuk mendapatkan pemahaman yang mendalam tentang masalah-masalah manusia dan sosial, bukan mendeskripsikan bagian permukaan dari suatu realitas sebagaimana dilakukan penelitian kuantitatif dengan positivismenya. ${ }^{4}$ Penelitian ini merupakan penelitian kepustakaan atau literatur (library research) yang memfokuskan kajiannya pada buku-buku yang berhubungan dengan penelitian yang dilakukan, sekaligus memperoleh data penelitiannya melewati buku tersebut tanpa harus terjun langsung ke lapangan. ${ }^{5}$

Pengumpulan data pada penelitian ini menggunakan teknik dokumentasi, yaitu suatu teknik penelitian dengan menggunakan berbagai sumber yang digunakan untuk melengkapi penelitian, baik berupa sumber tertulis, film, gambar, dan karya-karya monumental, yang semuanya itu memberikan informasi bagi proses penelitian. ${ }^{6}$ Kegiatan dokumentasi sangat penting dilakukan dalam rangka menguji keserasian antara idealita dan realita yang ada dari penelitian yang sedang dilakukan.

\section{HASIL DAN PEMBAHASAN}

\section{A. Definisi Motivasi}

Istilah motivasi berasal dari kata motif yang dapat diartikan sebagai kekuatan yang terdapat dalam diri individu, yang menyebabkan individu tersebut bertindak atau berbuat. Motif tidak diamati secara langsung, tetapi dapat diinterpretasikan dalam tingkah lakunya, berupa rangsangan, dorongan, atau pembangkit tenaga munculnya suatu tingkah laku tertentu. ${ }^{7}$

\footnotetext{
${ }^{4}$ Imam Gunawan, “Metode Penelitian Kualitatif,” Jakarta: Bumi Aksara 143 (2013): Hal. 85.

${ }^{5}$ Mestika Zed, Metode Peneletian Kepustakaan (Yayasan Obor Indonesia, 2004), Hal. 2.

${ }^{6}$ Gunawan, "Metode Penelitian Kualitatif," Hal. 85.

${ }^{7}$ A. Usmara, "Motivasi Kerja: Proses, Teori, Dan Praktik," Yogyakarta: Amara Books, 2006, Hal. 12.
} 
Motif adalah daya penggerak dalam diri seseorang untuk melakukan aktifitas tertentu, demi mencapai tujuan tertentu. Menurut Pinder motivasi adalah suatu kumpulan kekuatan tenaga yang berasal baik dalam maupun luar individu yang memulai sikap dan menetapkan bentuk, arah, serta intensitasnya. ${ }^{8}$ Dari definisi tersebut dapat ketahui bahwa motivasi muncul karena adanya kebutuhan, yang kemudian menggerakkan seseorang untuk mendapatkan kebutuhan tersebut.

Berkaitan dengan pengertian motivasi, beberapa psikolog menyebut motivasi sebagai konstruk hipotesis yang digunakan untuk menjelaskan keinginan, arah, intensitas, dan keajegan perilaku yang diarahkan oleh tujuan. Dalam motivasi tercakup konsep-konsep, seperti kebutuhan untuk berprestasi, kebutuhan berafiliasi, kebiasaan, dan keingintahuan seseorang terhadap sesuatu.

Apabila dilihat dari sumber kemunculannya, motivasi dibedakan menjadi dua macam, yaitu motivasi instrinsik dan motivasi ekstrinsik.

1. Motivasi instrinsik bersumber dari rangsangan dari dalam diri atau tidak memerlukan rangsangan luar disebabkan adanya rangsangan dari dalam diri individu, karena sesuai dengan kebutuhannya. Misalnya seseorang ingin belajar sejarah agar mendapatkan pengetahuan yang sesuai dengan minat dan urgensi dari ilmu tersebut maka faktor ini berasal dari dalam dirinya sendiri.

2. Motivasi ekstrinsik ialah motivasi yang timbul karena adanya rangsangan dari luar individu, misalnya seseorang yang mengikuti perlombaan karena ingin menjadi juara satu. Jadi keinginan untuk menjadi juara satu merupakan faktor yang berasal dari luar diri individu. ${ }^{?}$

Motivasi intrinsik dan motivasi ekstrinsik bergantung pada waktu dan konteks. Keduanya mencirikan individu-individu pada suatu waktu dalam kaitannya dengan aktifitas tertentu. Aktifitas yang sama bisa jadi secara intrinsik

8 Ibid., Hal. 14.

${ }^{9}$ Wina Sanjaya, Kurikulum Dan Pembelajaran (Teori \& Praktek KTSP) (Kencana, 2008), Hal. 256. 
atau secara ekstrinsik motivasi orang yang berbeda. Hal itu dikarenakan motivasi intrinsik bersifat kontekstual, motivasi intrinsik dapat berubah seiring waktu. ${ }^{10}$

Kebutuhan yang harus dipenuhi oleh setiap orang mengakibatkan mereka berusaha semaksimal mungkin untuk meraihnya. Motivasi yang berangkat dari kebutuhan (need) ini dapat menggambarkan perilaku seseorang secara umum. Namun untuk meraih apa yang diinginkan, seseorang memerlukan suatu interaksi sebagai langkah untuk menggapai kebutuhan. Proses interaksi ini disebut sebagai motivasi dasar (basic motivations). ${ }^{11}$ Model motivasi dasar ini dapat dilihat pada gambar sebagai berikut:

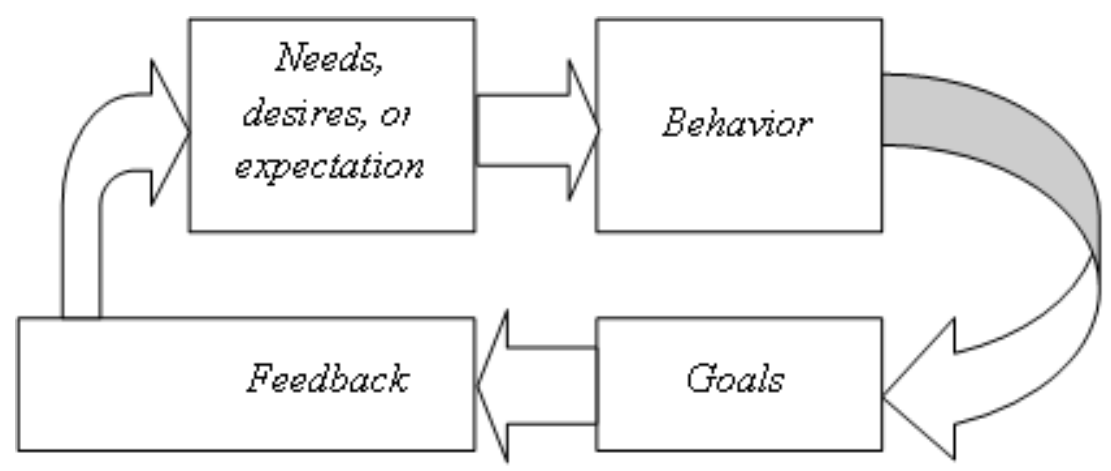

\section{Gambar 1. Proses motivasi dasar}

Model diatas merupakan serangkaian interaksi yang harus dilalui seseorang terkait berbagai kebutuhannya. Hal yang paling dasar mengawali kebutuhan tersebut ialah adanya kebutuhan atau ekspektasi yang ingin dicapai, berangkat dari kebutuhan ini maka akan mendorong seseorang untuk berperilaku. Perilaku tersebut harus mengarahkan seseorang agar kepada kebutuhannya, apabila perilaku tersebut menyimpang dari kebutuhan yang ditetapkan maka yang terjadi adalah kegagalan.

Adapun perilaku yang sesuai akan mengarahkan kepada tujuan yang dicapai. Jika tujuan sudah didapatkan maka seseorang akan memerlukan umpan balik baik dari seseorang maupun dari dalam dirinya tentang kebutuhan yang diinginkannya. Apakah kebutuhan tersebut sudah sesuai ekspektasi atau belum. Ketika

10 Dale H. Schunk, Paul R. Pintrich, and Judith L. Meece, "Motivasi Dalam Pendidikan: Teori, Penelitian, Dan Aplikasi," Jakarta: PT. Indeks, 2012, Hal. 359.

${ }^{11}$ Hamzah B. Uno, Teori Motivasi \& Pengukurannya: Kajian \& Analisis Di Bidang Pendidikan, 2008, Hal. 5. 
kebutuhan seseorang telah didapatkan, maka muncul dua pilihan, apakah akan mencari kebutuhan yang lain atau mempertahankan kebutuhan tersebut. Oleh karena itu interaksi ini terus berulang terus menerus pada diri seseorang.

\section{B. Teori Motivasi Berprestasi McClelland}

Keinginan untuk meraih prestasi mutlak dimiliki setiap orang, beragam cara yang ditempuh seseorang untuk menggapainya. Semakin tinggi prestasi yang diinginkan maka semakin keras pula usaha yang harus ia keluarkan. McClelland dalam hal ini mengembangkan suatu bentuk motivasi yaitu motivasi berprestasi. Motivasi berprestasi ini kebutuhan yang diperoleh sejak kecil dan terus dikembangkan pada saat seseorang menginjak kedewasaan.

Pentingnya motivasi berprestasi akan menumbuhkan sikap yang positif bagi manusia. saking termotivasinya seseorang pada suatu prestasi, ia akan selalu menerima dengan senang respon atau nasihat dan saran tentang cara meningkatkan prestasinya. ${ }^{12}$ McClelland menjelaskan karakteristik seseorang dengan kebutuhan prestasi yang kuat sebagai berikut:

1. Keinginan yang kuat untuk tanggung jawab pribadi

2. Keinginan timbal balik yang cepat dan kongkret dengan mempertimbangkan hasil dari pekerjaan mereka

3. Melakukan pekerjaan dengan baik; penghargaan moneter dan materi lainnya berhubungan dengan prestasi

4. Kecenderungan untuk mengatur tujuan prestasi yang layak

5. Manusia dengan kebutuhan prestasi yang kuat akan menghasilkan tingkat pencapaian tujuan yang tinggi

6. Suka mengambil tanggung jawab untuk menyelesaikan masalah

7. Menentukan target-target pencapaian masuk akal

8. Mengambil resiko-resiko dengan penuh perhitungan

${ }^{12}$ Uno, "Teori Motivasi \& Pengukurannya" Hal. 47. 
9. Berkemauan keras untuk memperoleh umpan balik atas kinerjanya. ${ }^{13}$

McClelland (1961) mengemukakan bahwa individu mempunyai cadangan energi potensial yang dapat dilepaskan atau dikembangkan tergantung pada dorongan motivasi individu, serta didukung oleh situasi dan kesempatan yang tersedia. Dengan demikian, motivasi untuk mengerahkan cadangan energy potensial tersebut menurut McClelland terpusat pada tiga bentuk kebutuhan, yaitu: 1) kebutuhan akan prestasi (need of achievement) disingkat $\mathrm{nAch}, 2$ ) kebutuhan akan kekuasaan (need of power) disingkat nPow, dan 3) kebutuhan akan afiliasi (need of affiliation) disingkat nAff. ${ }^{14}$

Penjelasan mengenai ketiga bentuk kebutuhan tersebut sebagai berikut:

1. Kebutuhan akan prestasi (need of achievement)

Kebutuhan prestasi akan mendorong seseorang berprestasi dalam keadaan bila target yang akan dicapai nyata dan memiliki peluang untuk diperoleh serta cenderung menimbulkan kreatifitas pada seseorang. Kebutuhan prestasi dirumuskan dan menetapkan bahwa pencapaian perilaku yang terkait adalah hasil dari konflik antara harapan sukses dan takut gagal. Kecenderungan pendekatan dan penghindaran terdiri dari fungsi kebutuhan pencapaian, harapan dari keberhasilan dan kegagalan, dan nilai insentif dari keberhasilan dan kegagalan. ${ }^{15}$

Menurut McClelland, setiap invididu memiliki kebutuhan sendiri-sendiri sesuai dengan karakter serta pola pikir yang membentuknya. McClelland menjelaskan bahwa setiap individu memiliki dorongan yang kuat untuk berhasil. Dorongan ini mengarahkan individu untuk berjuang lebih keras untuk memperoleh pencapaian pribadi ketimbang memperoleh penghargaan. Berdasarkan ketiga bentuk kebutuhan diatas, bentuk dorongan ini dapat dikategorikan sebagai nAch yaitu kebutuhan akan pencapaian atau prestasi. ${ }^{16}$

\footnotetext{
${ }^{13}$ Usmara, "Motivasi Kerja," Hal. 28.

14 Nanang Hasan Susanto and Cindy Lestari, "Problematika Pendidikan Islam Di Indonesia: Eksplorasi Teori Motivasi Abraham Maslow Dan David McClelland," Edukasia Islamika, 2018, Hal. 190.

15 Adim Indilla Dany, "Pengaruh Kebutuhan Prestasi, Kekuasaan, Dan Afiliasi Terhadap Kinerja Karyawan (Studi Pada Karyawan Asuransi Jiwa Bersama Bumiputera 1912 Cabang Batu)," Jurnal Administrasi Bisnis 24, no. 2 (2015), Hal. 2.

${ }^{16}$ Susanto and Lestari, "Problematika Pendidikan Islam Di Indonesia," Hal. 190.
} 
McClelland dalam Siagian menyatakan bahwa kebutuhan akan prestasi mempunyai dua indikator, yaitu: (1) Kemampuan adalah kecakapan dalam menguasai beberapa keahlian yang sudah menjadi bawaan sejak lahir atau dari latihan yang digunakan untuk mengerjakan sesuatu yang berwujud tindakan. (2) Kreativitas adalah kemampuan seseorang dalam menciptakan sesuatu yang baru, baik melalui pikiran maupun karya yang berbentuk sesuatu yang baru. ${ }^{17}$

\section{Kebutuhan akan kekuasaan (need of power)}

Kebutuhan akan kekuasaan (nPow) merupakan keinginan untuk memiliki pengaruh, menjadi yang berpengaruh, dan mengendalikan individu lain. McClelland merinci bahwa seseorang yang memiliki nPow tinggi, akan cenderung memiliki karakter bertanggung jawab, berjuang untuk mempengaruhi individu lain, senang ditempatkan dalam situasi kompetitif, dan berorientasi pada status sosial. Apabila dikaitkan dengan pendidikan, kebutuhan kekuasaan akan dapat membuat suasana belajar yang kompetitif. ${ }^{18}$ Kekuasaan adalah kemampuan individu atau kelompok untuk mempengaruhi tingkah laku orang atau kelompok lain sesuai dengan keinginan individu tersebut. Seseorang yang memiliki tingkat Kebutuhan Kekuasaan yang tinggi cenderung berperilaku lebih tegas. ${ }^{19}$

McClelland dalam Siagian mengemukakan bahwa kebutuhan akan kekuasaan mempunyai dua indikator penting, yaitu: (1) Aktualisasi diri adalah tersedianya kesempatan bagi seseorang untuk mengembangkan kemampuannya sehingga berubah menjadi kemampuan nyata dalam rangka untuk mendapatkan kekuasaan.

(2) Kekuasaan merupakan kemampuan seseorang dalam memperoleh sesuatu dengan cara yang dikehendakinya. ${ }^{20}$

3. Kebutuhan akan afiliasi (need of affiliation)

Kebutuhan ketiga yaitu nAff adalah kebutuhan untuk memperoleh hubungan sosial yang baik. Kebutuhan ini ditandai dengan kecenderungan seseorang yang

${ }^{17}$ P. Siagian Sondang, "Manajemen Sumber Daya Manusia," Jakarta: Bumi Aksara, 2008, Hal. 169.

18 Nanang Hasan Susanto, "Mengurai Problematika Pendidikan Nasional Berbasis Teori Motivasi Abraham Maslow Dan David Mcclelland," Lembaran Ilmu Kependidikan 47, no. 1 (2018): Hal. 33.

19 Dany, "Pengaruh Kebutuhan Prestasi, Kekuasaan, Dan Afiliasi Terhadap Kinerja Karyawan (Studi Pada Karyawan Asuransi Jiwa Bersama Bumiputera 1912 Cabang Batu),” Hal. 3.

${ }^{20}$ Sondang, "Manajemen Sumber Daya Manusia," Hal. 172. 
memiliki motif yang tinggi untuk terjalinnya sebuah persahabatan, lebih menyukai situasi kooperatif, dan menginginkan hubungan-hubungan yang melibatkan tingkat pengertian mutual yang tinggi. Dalam konteks pendidikan, kebutuhan afiliasi ini akan terwujud dalam proses pembelajaran dimana adanya interaksi baik guru dengan siswa maupun siswa dengan siswa. Kebutuhan akan afiliasi ini akan meningkat ataupun menurun sesuai dengan situasi. Misalnya saja ketika ada pembelajaran kelompok, maka nAff akan meningkat. ${ }^{21}$ Individu merefleksikan keinginan untuk mempunyai hubungan yang erat, kooperatif dan penuh sikap persahabatan dengan pihak lain. Individu yang mempunyai kebutuhan afiliasi yang tinggi umumnya berhasil dalam pekerjaan. ${ }^{22}$

McClelland dalam Siagian menyatakan kebutuhan afiliasi mempunyai dua faktor, yaitu: (1) Gairah kerja adalah perwujudan dari moral dan semangat kerja yang tinggi. Motivasi tersebut muncul jika seseorang tersebut mempunyai niat dan keinginan dalam mengerjakan tugasnya. (2) Interaksi dengan orang lain adalah suatu komunikasi yang dilakukan dengan orang lain, pada dasarnya setiap individu tidak dapat hidup sendiri dan saling membutuhkan dengan individu yang lain. $^{23}$

\section{Konsep Pendidikan Agama Islam}

UU No. 20 th 2003 menjelaskan tentang definisi pendidikan, yaitu usaha sadar dan terencana untuk mewujudkan suasana belajar dan proses pembelajaran agar peserta didik secara aktif mengembangkan potensi dirinya untuk memiliki kekuatan spiritual keagamaan, pengendalian diri, kepribadian, kecerdasan, akhlak mulia, serta keterampilan yang diperlukan dirinya, masyarakat, bangsa, dan negara. $^{24}$

Menurut Carter V. Good dalam bukunya Dictionary of Education menyatakan pengertian pendidikan adalah sebagai berikut:

${ }^{21}$ Susanto, "Mengurai Problematika Pendidikan Nasional Berbasis Teori Motivasi Abraham Maslow Dan David Mcclelland," Hal. 33.

22 Tria Meisya Aziti, "Pengaruh Motivasi Kekuasaan, Motivasi Afiliasi, Dan Motivasi Berprestasi Terhadap Kinerja Karyawan Pt X.," Management and Entrepreneurship Journal 2, no. 2 (2019): Hal. 74.

23 Sondang, "Manajemen Sumber Daya Manusia," Hal. 170.

24 Presiden Republik Indonesia, "Undang-Undang Republik Indonesia Nomor 20 Tahun 2003 Tentang Sistem Pendidikan Nasional,” Jakarta: Pemerintah Republik Indonesia, 2003, Hal. 2. 
"The systematized learning or instruction concerning principles and methods of teaching and of student control and guidance; largely replaced by the term education."

Pendidikan adalah ilmu yang sistematis atau pengajaran yang berhubungan dengan prinsip dan metode-metode mengajar, pengawasan dan bimbingan murid; dalam arti luas digantikan dengan istilah pendidikan. ${ }^{25}$ Sedangkan definisi pendidikan menurut Ahmad D. Marimba ialah bimbingan atau pimpinan secara sadar oleh si pendidik terhadap perkembangan jasmani dan rohani si terdidik menuju terbentuknya kepribadian yang utama. ${ }^{26}$

Adapun Hasbullah menjelaskan pendidikan menunjukkan suatu proses bimbingan, tuntunan atau pimpinan yang di dalamnya mengandung unsur-unsur seperti pendidik, anak didik, tujuan dan sebagainya. ${ }^{27}$ Dari beberapa pengertian diatas, pendidikan ialah suatu proses pembelajaran atau bimbingan untuk mengembangkan potensi yang dimiliki peserta didik, sehingga terbentuk suatu kepribadian yang berkarakter.

Adapun definisi pendidikan agama Islam menurut beberapa ahli pendidikan sebagai berikut:

1. Abudin Nata menjelaskan bahwa ilmu pendidikan Islam adalah ilmu yang membahas berbagai teori, konsep, dan desain tentang berbagai aspek atau komponen pendidikan: visi, misi, tujuan, kurikulum, proses belajar mengajar dan sebagainya yang didasarkan pada nilai-nilai ajaran Islam sebagaimana terdapat di dalam Al-Qur'an dan al-Sunnah. ${ }^{28}$

2. Menurut Roqib, ilmu pendidikan Islam adalah teori-teori kependidikan yang didasarkan pada konsep dasar Islam yang diambil dari penelaahan terhadap Al-Qur'an, Hadits, dan teori-teori keilmuan lain, yang ditelaah dan dikonstruksi secara integratif oleh intelektual muslim untuk menjadi sebuah

25 V. Carter, “Good, Dictionary of Education,” New York: McGraw Hill Book Co 195 (1959): Hal. 387.

${ }^{26}$ Ahmad D. Marimba, "Filsafat Pendidikan Islam," Bandung: Al-Ma'arif, 1989, Hal. 19.

${ }^{27}$ Dasar-dasar Ilmu Pendidikan Hasbullah and Edisi Revisi, Jakarta: PT Raja Grafindo Persada, (1996): Hal. 5.

28 Abuddin Nata, Ilmu Pendidikan Islam Multidisipliner: Normatif Perenialis, Sejarah, Filsafat, Psikologi, Sosial, Manajemen, Teknologi, Informatika, Kebudayaan, Politik, Hukum (Jakarta: PT. Grafindo Persada, 2010), Hal. 20. 
bangunan teori-teori kependidikan yang bisa dipertanggungjawabkan secara ilmiah. $^{29}$

3. Moh. Haitami Salim dan Syamsul Kurniawan mendefinisikan Pendidikan Islam ialah segala upaya atau proses pendidikan yang dilakukan untuk membimbing tingkah laku manusia, baik individu, maupun sosial untuk mengarahkan potensi, baik potensi dasar (fitrah), maupun ajaran yang sesuai dengan fitrahnya melalui proses intelektual dan spiritual berlandaskan nilai Islam untuk mencapai kebahagiaan hidup di dunia dan akhirat. ${ }^{30}$

Berdasarkan definisi dari beberapa ahli diatas, dapat disimpulkan bahwa pendidikan Agama Islam adalah ilmu yang membahas segala konsep tentang komponen pendidikan yang dilakukan untuk mengarahkan tingkah laku manusia sesuai dengan fitrahnya didasarkan pada nilai-nilai Islam yang terdapat dalam AlQur'an dan Al-Sunnah.

\section{Implikasi Motivasi Berprestasi dalam Pembelajaran PAI}

Berbagai penelitian yang menunjukkan bahwa motivasi berpengaruh terhadap prestasi belajar khususnya pembelajaran PAI, maka sudah semestinya motivasi perlu dipertimbangkan atau perlu dikembangkan agar motivasi peserta didik dalam belajar PAI terus meningkat. Apabila dianalisis lebih lanjut, implikasi dari teori McClelland dalam pembelajaran PAI sebagai berikut:

\section{Motivasi Berprestasi (n $A c h)$}

Dalam proses pendidikan, peserta didik bukan hanya diberikan pengetahuan saja melainkan juga diberikan nilai-nilai yang bersumber dari agama, sosial, budaya, teknologi, dan lain-lain. Selain itu lembaga pendidikan sudah menyusun sistem penilaian belajar sebagai tolak ukur keberhasilan peserta didik. Dengan demikian, hal tersebut akan memacu peserta didik untuk berprestasi dalam setiap proses pembelajaran termasuk pembelajaran PAI. Motivasi tersebut secara tidak langsung menjadi tantangan dan hambatan yang harus dilewati oleh peserta didik

${ }^{29}$ Moh Roqib, Ilmu Pendidikan Islam; Pengembangan Pendidikan Integratif Di Sekolah, Keluarga Dan Masyarakat (LKIS Pelangi Aksara, 2009), Hal. 15.

${ }^{30}$ Haitami Salim and Syamsul Kurniawan, "Studi Ilmu Pendidikan Islam," Jogjakarta: Ar-Ruzz Media, 2012, Hal. 33. 
dalam upaya mencapai tujuannya. Hal ini sebagaimana Nabi Muhammad Shallallahu Alaibi Wasallam bersabda:

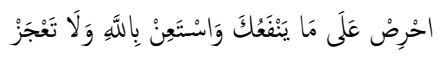

Artinya: Capailah dengan sungguh-sungguh apa yang berguna bagimu, mohonlah pertolongan kepada Allah Azza wa Jalla dan janganlah kamu menjadi orang yang lemah. ${ }^{31}$

Hadits diatas menunjukkan bahwa seseorang dituntut untuk bersemangat dalam mengerjakan hal-hal yang bermanfaat untuknya. Pendidikan merupakan kegiatan untuk membekali ilmu kepada peserta didik, melalui ilmu tersebut ia akan mengetahui apa yang harus ia lakukan apakah ia akan berbuat kepada hal yang bermanfaat atau berbuat sesuatu yang sia-sia.

Selanjutnya pembelajaran PAI hendaknya disisipkan nilai-nilai intrinsik yang akan mempengaruhi peserta didik untuk selalu berbuat baik. tidak mudah menyerah terhadap suatu hal, maka sudah semestinya guru juga membekali dirinya sebelum mengajarkan pendidikan Agama Islam kepada peserta didik. hal ini menguatkan penjelasan dari Abudin Nata bahwa pendidikan Islam itu desain tentang komponen pendidikan berupa proses belajar mengajar yang bersumber pada nilai-nilai ajaran Islam.

Salah satu prinsip strategi pembelajaran ialah menentukan aktifitas yang tepat sehingga tercapai tujuan pembelajaran. ${ }^{32}$ Guru hendaknya merancang kegiatan belajar yang sesuai dengan kondisi dan situasi peserta didik, termasuk metode, media, atau materi yang tepat khususnya materi PAI sehingga peserta didik semangat dalam mengikuti proses pembelajaran. Semakin matang persiapan guru dalam mengajar, maka semakin tinggi tingkat keberhasilan belajar peserta didik (prestasi).

2. Motivasi Kekuasaan (nPow)

31 https://www.hadits.id/hadits/muslim/4816. Diakses pada 10.36 am tanggal 01-03-2020.

32 Elihami Elihami and Abdullah Syahid, "Penerapan Pembelajaran Pendidikan Agama Islam Dalam Membentuk Karakter Pribadi Yang Islami," Edumaspul: Jurnal Pendidikan, Vol. 2, No. 1 (2018): Hal. 83. 
Teori McClelland tentang motivasi kekuasaan adalah keinginan untuk berkuasa, atau mempengaruhi individu lain, menjadi orang yang memiliki kedudukan. Namun dalam aspek pendidikan hal ini perlu diarahkan dengan baik khususnya pembelajaran PAI, dalam proses pembelajaran PAI motivasi kekuasaan ini hendaknya ditujukan untuk menciptakan rasa tanggung jawab dan amanah peserta didik atas kelompok belajarnya, selain itu pembelajaran PAI ditujukan agar peserta didik minimal bisa menjadi pemimpin khususnya bagi dirinya sendiri. Allah Subhanabu Wa Ta'ala berfirman dalam Q.S Al-Baqarah ayat 30:

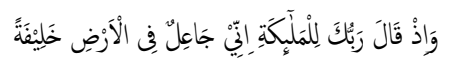

Artinya: Dan (ingatlah) ketika Tuhanmu berfirman kepada para malaikat, "Aku hendak menjadikan khalifah di bumi". 33

Ayat tersebut menerangkan bahwa manusia diberikan tanggung jawab menjadi pemimpin dimuka bumi. Dengan demikian, semua manusia adalah pemimpin, setidaknya mereka akan memimpin diri mereka sendiri termasuk juga peserta didik. Dengan demikian, menguasai diri sendiri merupakan ajaran Islam dimana pendidikan Islam berperan untuk mengarahkan seseorang dalam bertingkah laku sesuai fitrahnya agar mencapai kebahagiaan dunia dan akhirat sebagaimana penjelasan Moh. Haitami dan Syamsul Kurniawan mengenai konsep Pendidikan Agama Islam.

Peserta didik yang memiliki jiwa seorang pemimpin akan merasa bertanggung jawab dengan segala konsekuensi dari tugas yang diberikan oleh guru, baik ketika mengerjakan tugas sekolah ataupun diluar sekolah. Sehingga rasa tanggung jawab tersebut menjadi modal yang cukup baginya untuk meniti kehidupan di masa mendatang. Dorongan untuk berkuasa/memimpin tersebut sangat dipengaruhi oleh faktor intrinsik dan ekstrinsik, oleh karena itu tidak semua peserta didik dapat memahami dan menyadari hal tersebut.

Peserta didik yang mampu menguasai dirinya untuk tidak mengikuti hawa nafsu merupakan dampak positif dari motivasi kekuasaan. Hal ini disebabkan

33 https:/ /itequran.net/al-baqarah. Diakses pada 11.06 am tanggal 01-03-2020. 
karena ia mampu menentukan pilihannya secara bijak. Sedangkan peserta didik yang tidak bisa mengontrol hawa nafsunya, cenderung akan melakukan keburukan-keburukan bagi diri peserta didik maupun keburukan bagi orang lain.

3. Motivasi Afiliasi ( $\mathrm{n}$ Aff)

Manusia adalah makhluk sosial, maksudnya ialah memerlukan individu lain dalam kehidupan bersosial. Begitu pula dalam pendidikan, terdapat motivasi berafiliasi diantara peserta didik. Lembaga pendidikan berperan penting dalam menumbuhkan jiwa sosial peserta didik, banyak kegiatan pembelajaran yang bisa disusun oleh guru agar peserta didik saling bekerjasama dengan peserta didik yang lain. Misalnya ketika guru memberikan tugas kelompok kepada peserta didik, maka yang terjadi adalah peserta didik akan saling bahu membahu menyelesaikan tugas tersebut. interaksi diantara peserta didik inilah yang mendorong mereka untuk berafiliasi. Allah Subhanahu Wa Ta'ala berfirman dalam Q.S Al-Hujurat ayat 13:

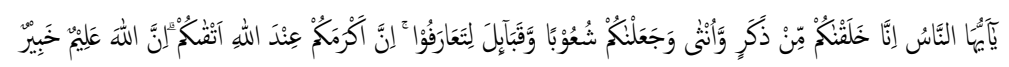

Artinya: Wahai manusia! Sungguh, Kami telah menciptakan kamu dari seorang laki-laki dan seorang perempuan, kemudian Kami jadikan kamu berbangsa-bangsa dan bersuku-suku agar kamu saling mengenal. Sesungguhnya yang paling mulia di antara kamu di sisi Allah ialah orang yang paling bertakwa. Sungguh, Allah Maha Mengetahui, Mahateliti. ${ }^{34}$

Ayat diatas menunjukkan bahwa manusia diciptakan untuk saling mengenal satu sama lain dan saling berinteraksi. Konsep pembelajaran pendidikan Agama Islam setidaknya dirancang agar menyiapkan peserta didik menjadi pribadi yang berjiwa sosial, peka terhadap lingkungan, dan membantu orang-orang yang membutuhkan pertolongan.

Motivasi berafiliasi dalam pembelajaran PAI bisa juga terjadi diantara guru dan peserta didik. Dimana guru sebagai fasilitator akan memberikan contohcontoh yang baik sesuai Al-Qur'an dan Sunnah kepada peserta didik bagaimana cara berinteraksi dengan orang lain. Peserta didik yang memiliki jiwa sosial yang

34 https:/ / litequran.net/al-hujurat. Diakses pada pukul $1.32 \mathrm{pm}$, tanggal 01-03-2020. 
baik akan mudah diterima dalam lingkungan sekolah, masyarakat maupun keluarga, karena ia mampu menempatkan dirinya sesuai kondisi yang terjadi ditempatnya. Semakin baik motivasi berafiliasi peserta didik, maka semakin baik pula hubungannya dengan orang lain.

\section{KESIMPULAN}

Artikel ini menunjukkan bahwa teori motivasi McClelalland yaitu motivasi prestasi, motivasi kekuasaan, motivasi berafiliasi erat kaitannya dengan pembelajaran pendidikan Agama Islam. Motivasi tersebut sangat dipengaruhi oleh faktor intrinsik dan ekstrinsik. Dalam pembelajaran PAI, peserta didik diajarkan ilmu pengetahuan agama yang bertujuan agar ia memiliki semangat meraih cita-cita, rasa tanggung jawab dalam mengerjakan tugas dan menumbuhkan jiwa sosial kepada lingkungan sekitarnya. Semua motivasi tersebut tidak hanya dapat dirasakan peserta didik, melainkan guru dan pihak yang terkait dalam pendidikan juga dapat merasakan manfaatnya. Oleh karena itu, motivasi dapat menjadi pendorong seseorang untuk mencapai kesuksesan yang diinginkannya.

\section{DAFTAR PUSTAKA}

Aziti, Tria Meisya. "Pengaruh Motivasi Kekuasaan, Motivasi Afiliasi, Dan Motivasi Berprestasi Terhadap Kinerja Karyawan PT X" Management and Entrepreneurship Journal. Vol. 2, No. 2 (2019): 71-82.

Carter, V. "Good, Dictionary of Education.” New York: McGraw Hill Book Co 195 (1959): 448.

Dany, Adim Indilla. "Pengaruh Kebutuhan Prestasi, Kekuasaan, Dan Afiliasi Terhadap Kinerja Karyawan (Studi Pada Karyawan Asuransi Jiwa Bersama Bumiputera 1912 Cabang Batu).” Jurnal Administrasi Bisnis 24, no. 2 (2015).

Elihami, Elihami, and Abdullah Syahid. "Penerapan Pembelajaran Pendidikan Agama Islam Dalam Membentuk Karakter Pribadi Yang Islami.” Edumaspul: Jurnal Pendidikan 2, no. 1 (2018): 79-96.

Gunawan, Imam. “Metode Penelitian Kualitatif.” Jakarta: Bumi Aksara 143 (2013).

Hasbullah, Dasar-dasar Ilmu Pendidikan, and Edisi Revisi. "Jakarta: PT." Raja Grafindo Persada 3013 (1996). 
Indonesia, Presiden Republik. "Undang-Undang Republik Indonesia Nomor 20 Tahun 2003 Tentang Sistem Pendidikan Nasional." Jakarta: Pemerintah Republik Indonesia, 2003.

Leonard, Leonard. "Kompetensi Tenaga Pendidik Di Indonesia: Analisis Dampak Rendahnya Kualitas SDM Guru Dan Solusi Perbaikannya.” Formatif: Jurnal Ilmiah Pendidikan MIPA 5, no. 3 (2016).

Marimba, Ahmad D. "Filsafat Pendidikan Islam.” Bandung: Al-Ma’arif, 1989.

Nata, Abuddin. Ilmu Pendidikan Islam Multidisipliner: Normatif Perenialis, Sejarah, Filsafat, Psikologi, Sosial, Manajemen, Teknologi, Informatika, Kebudayaan, Politik, Hukum. Jakarta: PT. Grafindo Persada, 2010.

Roqib, Moh. Ilmu Pendidikan Islam; Pengembangan Pendidikan Integratif Di Sekolah, Keluarga Dan Masyarakat. LKIS Pelangi Aksara, 2009.

Salim, Haitami, and Syamsul Kurniawan. "Studi Ilmu Pendidikan Islam.” Jogjakarta: Ar-Ruzz Media, 2012.

Sanjaya, Wina. Kurikulum Dan Pembelajaran (Teori \& Praktek KTSP). Kencana, 2008.

Santosa, Dwi Tri. "Faktor-Faktor Penyebab Rendahnya Motivasi Belajar Dan Solusi Penanganan Pada Siswa Kelas XI Jurusan Teknik Sepeda Motor.” E-Jurnal Pendidikan Teknik Otomotif-S1 13, no. 2 (2016).

Schunk, Dale H., Paul R. Pintrich, and Judith L. Meece. "Motivasi Dalam Pendidikan: Teori, Penelitian, Dan Aplikasi.” Jakarta: PT. Indeks, 2012.

Sondang, P. Siagian. "Manajemen Sumber Daya Manusia." Jakarta: Bumi Aksara, 2008.

Susanto, Nanang Hasan. "Mengurai Problematika Pendidikan Nasional Berbasis Teori Motivasi Abraham Maslow Dan David Mcclelland." Lembaran Ilmu Kependidikan 47, no. 1 (2018): 30-39.

Susanto, Nanang Hasan, and Cindy Lestari. "Problematika Pendidikan Islam Di Indonesia: Eksplorasi Teori Motivasi Abraham Maslow Dan David McClelland.” Edukasia Islamika, 2018, 184-202.

Uno, Hamzah B. Teori Motivasi \& Pengukurannya: Kajian \& Analisis Di Bidang Pendidikan, 2008.

Usmara, A. "Motivasi Kerja: Proses, Teori, Dan Praktik." Yogyakarta: Amara Books, 2006.

Zed, Mestika. Metode Peneletian Kepustakaan. Yayasan Obor Indonesia, 2004. 